InOedia $\quad \begin{aligned} & \text { InMedia } \\ & \text { The French Journal of Media Studies }\end{aligned}$

7.2. $\mid 2019$

Documentary and Entertainment

\title{
Gazing at "Fetishes" 2.0: Using the Spectacle Concept to Understand Consumer Cultures in the Age of Digital Capitalism
}

\section{Olivier Frayssé}

\section{(2) OpenEdition \\ Journals}

Electronic version

URL: http://journals.openedition.org/inmedia/1902

DOI: 10.4000/inmedia.1902

ISSN: 2259-4728

Publisher

Center for Research on the English-Speaking World (CREW)

\section{Printed version}

Date of publication: 15 December 2019

\section{Electronic reference}

Olivier Frayssé, "Gazing at "Fetishes" 2.0: Using the Spectacle Concept to Understand Consumer Cultures in the Age of Digital Capitalism", InMedia [Online], 7.2. I 2019, Online since 16 December 2019, connection on 27 January 2021. URL: http://journals.openedition.org/inmedia/1902 ; DOI: https:// doi.org/10.4000/inmedia.1902

This text was automatically generated on 26 January 2021.

(c) InMedia 


\title{
Gazing at "Fetishes" 2.0: Using the Spectacle Concept to Understand Consumer Cultures in the Age of Digital Capitalism
}

\author{
Olivier Frayssé
}

1 The advent of the Age of the Internet has renewed interest in the concept of the spectacle. Both the press and academic publications have emphasized the relevance of Debordian ideas to take stock of current developments in our societies in which the visual has colonized our lives to an unprecedented extent.

In 2012, columnist John Harris of The Guardian, who had been following Internet-related issues for several years, claimed that "the Society of the Spectacle offered in 1967 an eerily accurate portrait of our image-saturated, mediated times." He opened his piece on the famous first sentence of the Society of the Spectacle, a variation on the first sentence of the Capital: "In societies where modern conditions of production prevail, all life presents itself as an immense accumulation of spectacles. Everything that was directly lived has moved away into a representation." And while his "battered copy" of the book featured "an entranced cinema audience, all wearing 3D glasses," he had come to picture the "archetypal modern crowd" instead: "squeezed up against each other, but all looking intently at the blinking screens they hold in their hands, while their thumbs punch out an imitation of life that surely proves Debord's point ten thousand times over."1

In 2017, Marco Briziarelli \& Emiliana Armano edited The Spectacle 2.0: Reading Debord in the Context of Digital Capitalism, in which the contributors connected Debord to many dimensions of digital capitalism, including social media, artificial intelligence, singularity, and of course digital consumer culture, contrasting the Frankfurt school critique of consumer culture as alienation with the Birmingham school vision that it can be seen as a shock absorber, a way to negotiate change, and also reconciliating the two approaches, since Douglas Kellner wrote the preface. ${ }^{2}$ 
This paper investigates the relevance of the concept of spectacle to understand the consumer cultures that have grown in the world of digital capitalism. ${ }^{3}$ It starts from the premise that Debord's La Société du Spectacle was a syncretism of contemporary - mainly US or US-based - criticism of the consumer society and of the power of the image on the one hand, and of the Marxist tradition on the other hand, with a convergence around the notion of fetishism. This syncretism took place at a precise moment in history, when Fordism and the consumer society submerged Europe after World War II. The research question becomes: what is the relevance of the spectacle concept in a post-Fordist world?

5 Its first section aims to elucidate the notion of commodity fetishism. The original Marxian concept established production and consumption as two sides of the same coin, one of which only was circulating and taken at face value. The Debordian concept of the spectacle, which presents itself as a détournement of Marx's notion of commodity fetishism, fails to adequately address the production side, which leaves ample room for other, often uncritical uses of the notion of fetishism that have dominated the discourse on the universal display of and quest for consumer products in the decades following 1967 and the publication of La Société du Spectacle. Clarification is therefore needed.

The second section establishes a theoretical framework connecting the evolution of consumption cultures with that of production cultures and provides a short historical sketch of their intertwined development under capitalism before the advent of Fordism in terms of their visual dimension.

7 The third section analyzes Debord's development of the notion of spectacle as a result of his fascination for and rejection of American consumer and visual cultures, which led him to develop a syncretism of critical American theories and the Hegelian-Marxist tradition.

8 The last and conclusive section addresses the relevance of the concept of spectacle in the digital era.

\section{Debord v. Marx: the concept of the spectacle v. commodity fetishism}

Debord does not make it very easy to understand his concept of the spectacle: the spectacle is a materialized Weltanschauung (thesis 5) that has made reality recede into it (thesis 1), creating from an abstracted part of reality a separate pseudo-world (images detached from life and merged into a stream) that provides an object that can only be contemplated and provides a unified and illusory reality: "The spectacle is a concrete inversion of life, an autonomous movement of the nonliving" (thesis 2), "a visible negation of life - a negation that has taken on a visible form" (thesis 10). The spectacle is visible in "particular manifestations -- news, propaganda, advertising, entertainment" (thesis 6), and "presents itself simultaneously as society itself, as a part of society, and as a means of unification" (thesis 3 ) through separation; it is at the same time a "model" for society (thesis 6), a separate sector that is "the focal point of all vision and all consciousness" (thesis 3), and it also "serves as a total justification of the conditions and goals of the existing system" (thesis 4): thus it is the material form of ideology (thesis 212), it is even ideology par excellence, since the "essence" of ideology is 
"the impoverishment, enslavement and negation of real life" (thesis 215). At the same time, it is a "social relation between people that is mediated by images" (thesis 4); this social relation is rooted in the mode of production since the spectacle is "the omnipresent affirmation of the choices that have already been made in the sphere of production and in the consumption implied by that production", and the spectacle is both the "result and the project" of this mode of production (thesis 6).

Now add a sprinkling of the Barthes of Mythologies, and you get Baudrillard, with the production and consumption of signs replacing the production and consumption of images, which have themselves replaced the production and consumption of "material things". The problem here with Debord is that he relates the society of the spectacle to the Marxist concept of commodity fetishism, enrolling Lukacs and his reification concept, as he does in thesis 67, describing a key-ring collector, who "accumulates the indulgences of the commodity, a glorious sign of its real presence among the faithful. Reified man proudly displays the proof of his intimacy with the commodity. Like the old religious fetishism, with its convulsionary raptures and miraculous cures, commodity fetishism generates its own moments of fervent exaltation."

11 This détournement of the Marxist concept of commodity fetishism is problematic, since the original concept has nothing to do with adoration of commodities, brands, or their images. It points to a Debordian vision of the connection between production and consumption that lacks both nuance and any real care for the actual situation of workers, their lives, their organization, which were at the heart of Marx's life and work. What exactly are the labor processes and exploitation mechanisms that need to be obscured by ideology, of which commodity fetishism is a component? The problem with Debord's works, apart from some of his cinematographic productions, is that they pay attention to the manner in which the labor processes and class relations are hidden (the spectacle) rather than to the realities of these labor processes and class relations. And, by focusing on that side of the coin, he makes room for an understanding of commodity fetishism that twists the original concept and leads to confusion.

What led Marx to write about commodity fetishism is the fact that, when we evaluate commodities, we do not see what makes them values in exchange and thus provides them with the character of commodities, id est the socially necessary quantity of labor that they contain, inseparable from the social conditions in which they are produced, the social relationship that is capital itself. We, instead, see that exchange value in the material properties of the things themselves, we believe that a diamond is more valuable than a chunk of coal because it is a diamond and not a chunk of coal. ${ }^{4}$

13 The word fetish, for Marx, has nothing to do with either its ethnological or psychoanalytical meanings. It comes from an analogy with the realm of religion: while deities are just "productions of the human brain", they are endowed by their creators (us) with the character of "independent beings endowed with life and entering into relation both with one another and the human race." Likewise, commodity fetishists, who do not understand that the value of commodities comes from their being the products of human labor, believe that they have an intrinsic value that derives only from their own independent material characteristics, and can therefore enter into relationships.

This "commodity fetishist" does not have any fixation on one particular commodity, or on commodities in general, this fetishist does not invest its libido in a metonymical fashion, nor does he or she look desperately for the mother's penis, and Bataille's The Eye would be a perfect stranger to him or her. ${ }^{5}$ This fetishist is defined by blindness 
rather than vision; far from adding to the object, of investing meaning in it, he or she sees only coal in coal and diamond in diamonds.

What Marx was discussing in that section of the Capital is not alienation but exploitation, since the social character of labor that is hidden by commodity fetishism is the fact that it is exploited under the conditions of capitalism, whereas Debord's focus is on "alienation" from "authentic life" by the endless pursuit of commodities while survival needs are already satisfied in the abundance economy, or affluent society, hence his notion of pseudo-needs, which is at odds with Marx's definition of human needs which is infinitely more liberal, and much closer to what marketing practitioners have observed:

"The commodity is, first of all, an external object, a thing which through its qualities satisfies human needs of whatever kind. The nature of these needs, whether they arise, for example, from the stomach, or the imagination, makes no difference." 6

So what Debord discusses is the consumer's alienation from his or her "true desires", a non-Marxist concept, which is Marxified by references to modes of production and even "capitalism", quite late in the book, in thesis 56. It springs from a normative vision of what real life should be, of what constitutes authentic desires, making Debord a moralist. ${ }^{7}$ What Debord calls commodity fetishism, as a driving force generating consumption, is but a fetish. So is the commodity itself, when he strips Marx's prosopopœia from its rhetorical character to transform the commodity, and the spectacle, into actors of history. Similarly, the function of ideology, of which consumer culture is a component, is not to negate "life" in abstracto, but to mask the realities of domination and exploitation in the production sphere. This is why we need to set foot on the shop floor as we go shopping for meaningful visions of the commodity, lest we fall victims to something like commodity fetishism ourselves.

\section{Consumer cultures, working cultures and stages of capitalism: before the spectacle}

18 Following Zygmunt Bauman, ${ }^{8}$ let us define culture as the set of social practices, symbolic representations, values and beliefs that are common to members of a social group as they interact, both materially and cognitively with the world they live in, and which precisely enables them to form such a group (and subgroups, with the concept of subculture). A large part of what characterizes these cultures is what and how people produce and consume, which is what has been recognized by the "material turn" in (cultural) history.

19 Since everything we consume has been produced, there is an obvious, tautological connection between what is consumed and what is produced, but there are also less obvious links, notably in the way we consume, and the way commodities are produced. Generally speaking, consumer culture cannot be abstracted from working culture.

In the sphere of production, it is helpful to combine the concepts of labor regimes and production regimes to account for the social reality that is production as a cultural fact, in other words a working culture. The concept of labor regime as defined by Mingione points to "the relatively coherent and permanent set of social rules which enable to mobilize the energy of workers in typical forms." 9 The "typical forms" relate to the worker's status: slave, servant, self-employed, waged worker, free-lancer etc.; to the 
work environment: family production units, on farms or in shops, vast aggregations of otherwise unrelated individuals in manufactures, factories, bureaucracies, etc.; to the division of labor between the sexes and the genderization of occupations; but also to the role of the state, the existence and nature of "welfare" systems, the construction of the notion of "good jobs" by educational systems and the media, etc. Professional cultures are particular expressions of the prevailing labor regime in given segments of the labor force. In other words, the labor regime concept addresses the question of what makes us work in typical forms.

The concept of production regimes is inspired by Marxism and especially Gramsci: it relates to the typical forms of the work / labor processes, which have an immediate effect on workers and result in changes in society at various levels, including consumption patterns. In other words, the concept addresses the question of what working under specific conditions, in typical forms, does to you.

There is an immediate connection at the individual level between the working culture and the consumer culture. What we consume and how we consume it is partly conditioned by the labor regime we are in, as materialized by our professional culture and its norms: in the US, starting in the 1920s, "office girls" were expected to dress up and use make-up before showing up at the office; today hypercharged executives of both sexes are expected to work out in the early morning hours and to chill out in bars in the evening. The production regime as such also influences consumption: having to bring one's lunchbox to a construction site, to purchase anti-inflammatory drugs to alleviate work-induced musculoskeletal disorders or to use mass transit systems to commute are consumption patterns dictated by the practical necessities related to the work process.

But the main connection is between the general framework of production and the general framework of consumption. We will begin by connecting the evolution of consumer culture with the evolution of the production of commodities under capitalism. This analysis will shed light on the specific ways commodities have been produced, commercialized and seen in different periods.

The phrase "consumer culture" lumps together all the various subgroups of all societies into a one-dimensional group characterized by its consuming activity. Are we then starting on the wrong foot? Yes and no. Yes, because the world markets - and the national markets 医 remain socially and culturally segmented. Globalization progresses through a complex process of homogenization, creolization, resistance, acculturation and appropriation of consuming patterns. No, because if we define "consumer culture [as] a system in which consumption, a set of behaviors found in all times and places, is dominated by the consumption of commercial products," 10 i.e. commodities. Consumer culture, in that sense, has been in existence since the advent of capitalism:

"Consumption is the sole end and purpose of all production; and the interest of the producer ought to be attended to only so far as it may be necessary for promoting that of the consumer." ${ }^{11}$ This definitive pronouncement by Adam Smith provides the foundational belief that society's goal is to enable its participants to consume. In that sense, it can be said to be an early definition of "consumer culture," understood not only as a set of social practices such as inspecting, purchasing, using commodities, which will be discussed hereafter, but also a set of values, including consumer sovereignty, which lays at the center of liberal and neo-liberal discourses. ${ }^{12}$ It appeared with the impressive expansion of manufacturing production that signaled the advent of 
capitalism as a dominant mode of production. At the same time, the irruption of a multitude of new objects in urban landscapes tickled the sense of vision more than the other senses.

The spectacle, as conceptualized by Debord, is typical of what has been called the Fordist phase of capitalism but has roots in the history of capitalism in the $19^{\text {th }}$ century.

"The wealth of bourgeois society, at first sight, presents itself as an immense accumulation of commodities, the individual commodity being its elementary form." The English translation of the first sentence of The Capital fails to completely capture the importance of the sense of sight, of visual inspection, that infuses the original German: "Auf den ersten Blick erscheint der bürgerliche Reichtum als eine ungeheure Warensammlung, die einzelne Ware als sein elementarisches Dasein." ${ }^{13}$

In the $19^{\text {th }}$ century, Marx and his contemporaries could conceptualize the monstrous (ungeheure) accumulation of commodities that resulted from the expansion of capitalism by looking at the impressive statistics of production and consumption. They also could simply trust their eyes as they witnessed the increasing number of manufactured objects of all sorts that were visible in the public and private spaces in cities, long before Baudrillard acknowledged a need to make sense of the profusion of objects in his introduction to Le Système des Objets. ${ }^{14}$

Capitalism encompasses many "modes of production" i.e. modes of producing commodities, often described as stages, within the capitalist mode of production as one, whose essence is to produce capital. For the purpose of this study, three stages of capitalism must be distinguished: a pre-Fordist stage, covering the $18^{\text {th }}$ and $19^{\text {th }}$ centuries; Fordism, dominating most of the $20^{\text {th }}$ century; and what remains an elusive and hotly debated concept, the post-Fordist era in which we live. Each stage has its own characteristic production and labor regimes, and also specific modes for the display of commodities. Europe initiated the pre-Fordist stage, the US both the Fordist and postFordist stages.

Pre-Fordist capitalism, originating in urbanized Europe, was based on the production of manufactures. Manufactures, as the name indicates, are handmade commodities, the human hand being supplemented by tools and machines. The associated labor regime emphasized skills, artisan-like values, manhood as control and independence, etc, away from the service model that had been paradigmatic before, now reserved for women and other subalterns. While the quantity of commodities produced seemed "monstrous" when compared to previous eras, most of manufactured production consisted in producer goods, and limited series of bespoke consumer goods for a restricted market of more or less well-to-do customers. The inability of the print media, all born as "advertisers", to account for the increasing diversity and sophistication of the new manufactures with their crude black and white drawings, became obvious. These miraculously new commodities, the nouveautés, had to be personally and visually inspected by prospective customers. The early $19^{\text {th }}$ century saw the invention of loci of mediation: the shop-window, of the Parisian Arcades and department stores, or of the British Crystal Palace that housed the World exhibition of 1851. All catered to this need of companies to communicate about their wares in an effective manner and also appealed to seekers of epistemic and aesthetic pleasures, the "flâneurs" described by Walter Benjamin, who also remarked on the significant link of world exhibitions with the entertainment industry. ${ }^{15}$ This new consumer culture 
extended to rural areas via peddlers, small-town shops and fairs, again through a faceto-face relationship with the commodity.

31 And the logic of exhibitions crossed the Atlantic, landing in New York, with the emblematic New York Crystal Palace, modeled after the British one, over whose shortlived destiny P. T. Barnum presided. In 1851, Barnum had profitably drawn crowds to his "grand moving show of the Crystal Palace," in Broadway, "a slowly revolving panorama that he called 'a progressive mirror" that showcased the London showcase, thereby indirectly promoting its future American clone. ${ }^{16}$ This was a harbinger of the next stage, where images, and moving images at that, would replace exhibitions as the main mode of presentation of commodities, now re-presentations 嶝 the age of Fordism.

\section{The notion of spectacle and the Americanization of the world: the Fordist moment}

Fordist capitalism was a US born model that was painstakingly and painfully imported worldwide. It involved mass production of rather poorly differentiated commodities, its original emblem being the Model T Ford, famously available in every color, provided it was black, and affordable for a large mass of those members of the working classes that shared in the benefits of increased productivity. With the assembly line, men became auxiliaries of the machine, which paved the way for the automation of an increasing number of processes. The labor regime deriving from this new production regime redefined the value of work and masculinity. ${ }^{17}$ It fixed the respective roles of the sexes in the production and reproduction spheres even more rigidly than before.

The reproduction sphere became increasingly organized around the consumption of commodities. And photography, billboards, the cinema, and especially television became the main mass media through which the commodity was made visible to the public, to the extent that the commodity itself was better presented by the "seen on TV" label than in its "naked truth". The phrase mass media carries two meanings: they serve a large public (the masses) with relatively standardized products, which are mass produced, and this involves a huge concentration of the means of production and distribution of images. This is the historical moment Debord's notion of the spectacle testifies to: it was a product of Debord's own exposure to the typically American visual culture that swamped Europe after World War II together with Fordist production methods; and it was an echo of the critics of the same that had developed in the US.

Debord's development of the notion of spectacle is both a reaction to the influence of American visual culture and a syncretism of American theories of the consumer society and visual culture and the Hegelian-Marxist tradition. What Debord was denouncing in his own language is what the US counterculture had labeled the consumer society ${ }_{20}$ a term coined in the US as early as 1920 by Norman Hapgood, and which was to be made popular in France by Baudrillard's book in 1970 (especially one of its dimensions, what Boorstin called the power of the image). ${ }^{18}$

In the 1950s, in the "Western" developed countries, the paradigmatic consumption mode became mass consumption of commodities, a mode that slowly emerged during industrialization and triumphed with Fordism. It involved long-circuit distribution, and visual inspection of commodities was increasingly replaced by visual inspection of packages, recognition of brands, and exposure to advertisement, hence the growing 
"power of the image", in the words of Daniel Boorstin. Boorstin discovered the power of the image by watching the Kennedy-Nixon debates and their effect on the election. Just like the relatively recently invented breakfast cereals, politicians could no longer be inspected directly by the voter / consumer, but had to be packaged and sold on TV, often using what Boorstin called "spectacular" "pseudo-events." While exhibitions and fairs continued in existence, most of the encounters with commodities were through images, and the consumer was one step removed from the actual commodity.

Non-Americans were often sharper in their perception of the changes that had happened in the US. In the US, the changes were incremental, and it took some time, even to brilliant and erudite thinkers like Boorstin, to realize that "a revolution," that is a qualitative change, had occurred, and he did that originally in the traditional form of the "American Jeremiad": "what happened to the American Dream?" the first subtitle of his The Image. When changes originating in the US, and which had already been largely implemented there, were exported elsewhere, they came as fully equipped models, and therefore struck observers as radically new, since completely foreign to their own cultures. Radically new, and with a distinct American flavor.

Antonio Gramsci, when he analyzed the Fordist production process and its consequences while jailed in Italy, had perceived this flavor, as both foreign and new, in the realm of production. Similarly, Debord was shocked by the changes in consumption habits and especially the changes in the urban settings that framed them, including the concrete bars that proliferated in the suburbs and figure prominently in his films that went along with the massive rural exodus that was taking place. One remembers that Debord, partly out of disgust with the changes made to Paris (already described in Tati's 1958 Mon Oncle) ended his life in the countryside. The young provincial who had moved to Paris during the Marshall Plan years was brutally exposed to US-inspired modernist architecture, merchandise and films. Classifying the list of films cited, detourned, or mentioned by Debord drawn up by Gabriel Ferreira Zacarias, one finds 3 French films, 1 Italo-Yugoslav production, 9 Soviet Bloc films (eight Russian, one from East Germany, to make room for the concept of "spectaculaire concentré" typical of the Soviet bloc, as opposed to "spectaculaire diffus" in the West), and 12 US movies, made in Hollywood. ${ }^{19}$ Just like Gramsci, who entitled his reflections Americanismo e Fordismo in 1934, Debord was ultimately to equal the development of the society of the spectacle with the "Americanization of the world" in his 1992 preface to the Society of the Spectacle. ${ }^{20}$ A similar case could be made for Baudrillard's America (1968).

Thus the idea of "consumer culture," as in "consumer society," here refers to what described one essential aspect of US society in the $20^{\text {th }}$ century, culminating in highFordism in the 1950s, and that was exported worldwide, buttressing similar developments in industrialized countries. The simple fact that the US accounted for over half of the world's exports in 1945 gave a distinct American flavor to the post-war expansion of mass consumption and the related consumer culture, as did the predominance of US cinema. By 1967, it had swarmed Europe, and had become the dominant paradigm, influencing other consumer cultures, even in developing countries, which Debord noticed in thesis 42 .

39 In terms of labor regime, what Debord described, as an obiter dictum, was the Fordist regime: subject to rigorous disciplines at work, the worker turned consumer in his leisure time now had the full attention of the specialists of domination: "At this point 
the humanism of the commodity takes charge of the worker's 'leisure and humanity' simply because political economy now can and must dominate those spheres as political economy' (thesis 43). Since survival is now guaranteed in the industrialized countries, the answer to the perennial question "how to make the poor work"12 includes the necessity of both making them consume commodities equated with goods and consume their leisure time in the spectacle, since it "monopolizes the majority of the time spent outside the production process" (thesis 6), away from any will to change the system, as "the spectacle is a permanent opium war designed to force people to equate goods with commodities and to equate satisfaction with a survival that expands according to its own laws." "Consumable survival must constantly expand because it never ceases to include privation," since pseudo-needs are constantly manufactured (thesis 44 ), while desire is asphyxiated.

While the Hegel / Feuerbach / Marx / Lukacs inspiration is evident in the Société du Spectacle and has been dealt with repeatedly by commentators, the book uses a wide array of concepts from 1950s and 1960s American sociology, notably Whyte and Riesman (mentioned in thesis 192), who had reflected on the changes in American society that had resulted from Fordism, Marcuse ${ }^{22}$, who had reconsidered Freud and Reich in the light of what Galbraith was to call the "Affluent Society ", an often misunderstood title, and Boorstin.

41 The French translation of Galbraith's book in 1961 was "L'ère de l'opulence" but Debord repeatedly used the word "abundance," together with "augmented survival" to describe the society where the satisfaction of basic needs, in his eyes, was no longer a problem. A lot of La Sociéte du Spectacle reminds one of what Galbraith called the dependence effect, when wants are created by the very process that satisfies them. "Consumer wants can have bizarre, frivolous, or even immoral origins, and an admirable case can still be made for a society that seeks to satisfy them. But the case cannot stand if it is the process of satisfying wants that creates the wants." ${ }^{23}$ While no evidence has yet been produced that Debord read Galbraith, the similarities are remarkable with several passages of $L a$ Société du Spectacle, such as theses 6 and 51. Thesis 6 uses a vaguely Marxist formulation to assert that the spectacle was "the omnipresent affirmation of the choices that have already been made in the sphere of production and in the consumption implied by that production," and thesis 51 posits that "when economic necessity is replaced by the necessity for boundless economic development, the satisfaction of primary human needs is replaced by uninterrupted fabrication of pseudo-needs which are reduced to the single pseudo-need of maintaining the reign of the autonomous economy."

42 From all these US influences, Boorstin's is probably the most important. He had observed the importance of images in modern life, and, while dismissing his and other American sociologists' critique of the consumer society as a "spectacular critique of the spectacle," Debord credits him with describing "the way the American spectacle was consumed as a commodity" (theses 196-198). ${ }^{24}$ The French translation, by Janine Claude, of The Image was published in 1963 by Julliard. ${ }^{25}$ It probably clarified Debord's concept of the spectacle, which he started using in $1960,{ }^{26}$ based on his study of the theater, especially Brecht's. Boorstin's use of the word "spectacular" and of the suffix "pseudo" must also have had an impact. Similarly, Debord's analysis of the mechanism of capitalist manipulation came from the reading of a French translation of Vance 
Packard's 1957's The Hidden Persuaders. ${ }^{27}$ The influence of Debord's reading of American authors is thus unmistakable.

The consumer culture that was paradigmatic in Debord's days was directly linked with the then paradigmatic labor regime, Fordism. Debord devoted much of his attention to the consumer culture that went hand in hand with Fordism and very little to the production side and the lives of workers, their resistance to exploitation, their demands for extra purchasing power, which would have been spent on more commodities. That Debord was essentially discussing Fordism is what Gianfranco Sanguinetti, in his Debordian dismissal of Apostolidès says when he ranks the Société $d u$ Spectacle, together with Huxley's Brave New World and Orwell's 1984 as the three important books of the $20^{\text {th }}$ century. ${ }^{28}$ That he stripped the concept of commodity fetishism from its reference to exploitation leaves labor a blind spot in his reflections on Fordism.

\section{Conclusion: what relevance for the spectacle concept in the digital era?}

Thus, Debord's failure to connect the production and the consumption sides leaves the concept of the spectacle somewhat deficient, less effective than that of commodity fetishism in its original sense, even in its visual dimensions. After all, the first sentence of the Capital, without the détournement, already included the notion of spectacle.

On the other hand, the picture of "alienation" from real life that emerged from $L a$ Société $d u$ spectacle and contributed to its success is indeed more valid than ever. In China, dedicated subdivisions of the concrete sidewalks have been created to prevent Smartphone addicts from bumping into real persons that they could not see because their sight was fixated on their screens. This could easily be read as an illustration of Debord's definition of the spectacle as a "concrete negation of life."

Thus, the advent of the Age of the Internet seems to have vindicated Debord's approach to the life vs. the spectacle issue. The multiplication of screens even suggests a mise en abyme of the concept as we spend an increasing part of our lives watching merchandise such as Smartphones that showcase the world as merchandise, from news to pornography and all sorts of consumer goods and services, and the omnipresent reality of the virtual expresses itself as in "second life" or "virtual reality" devices, and Pokemon Go. We are screened from reality by the reality of screens, which are like a film deposited on every possible surface, a film that lets us see something of the "reality out there" but reflects something else than what it covers, including ourselves.

What has changed since 1992, the last time Debord reflected on the society of the spectacle and characterized it as an Americanization of the world? To answer this question, it is best to ask first: what has not changed?

What has not changed is the soft power of the United States which keeps exporting the country's devotion to consumption ideals, consumer sovereignty, and the consumption of images. The Internet remains a very American thing, even in its Chinese version, and the mass consumer culture which remains at the core of US society keeps expanding worldwide, propelled by the GAFAM, Netflix, Hulu, Disney et. al. While rival powers develop their soft power within the same capitalist framework, they have had very limited impact on global tastes and consumption practices, all the more so as they have 
largely incorporated the core messages of the consumer society's promises. The metabolizing power of US capitalism has not only generated a "culture of diversity" in US consumer habits (many Americans think that pizza and tacos are as American as apple pie, which by the way is not either) but also recycled foreign consumption styles and marketed them worldwide. Whatever the efforts of America's competitors to differentiate culturally, the medium being the message, and the aim being similar (to realize surplus value), the paradigm of mass consumer culture remains unchanged. And this holds true of developing countries. Today, African underemployed workers who eat home-grown vegetables and maize flour mash also yearn for Smartphones and Internet surfing, and often manage to get them, by selling home-grown peanuts, fruit, sex and weed.

What has changed is the mix of labor regimes and consumer cultures that exist in the global supply chains and markets. The new paradigm for many production regimes might become logged-in: ${ }^{29}$ Work would start when you are logged-in, stop when you log-out, wherever you happen to be. This practice could become dominant in all the fields of production that are operated digitally and a paradigmatic labor regime could flourish, as Fordism emerged from the assembly line, but there is a long way to go in that direction.

The shift in consumption patterns, on the contrary, seems very rapid: the paradigmatic consumer culture on the Internet is surf and click, as opposed to stroll and pick in the supermarket. Then you get UPS and similar companies to deliver to your door or you U-Drive, which is a prosumer labor way of solving the "problem of the last mile."

What characterizes, from the view point of visualization, the rise of on-line purchasing, of the share of the Internet in advertising expenditure, and of social media viral marketing, is that the consumer is now two steps removed from the actual commodity: he sees not a photo of the commodity but a screen that showcases the photo of the commodity. The promise is similar to that of the advertising pictures in print media: "What you see is what you get." But with a twist. "What you see is what you get" was the name revolutionary visual editors gave to software developed in the 1970s which enabled users of writing software to see on-screen what would eventually come out of the printer. A promise made with some tongue-in-cheek innuendo for those who chose the WYSIWYG name, since it referred to a catchphrase repeated on the Flip Wilson Show by a male actor impersonating a female and referring to himself... What you see is a simulacrum, and this is indeed what you get, and what you don't see is the way both commodities and images are produced.

Here comes commodity fetishism in the original sense: this WYSIWYG promise itself obscures the conditions of production of the image, the regimes of production of these images. In the very alive Web 1.0, a free-lance photographer took a picture of the commodity, then uploaded it to a database. So-called independent contractors, like Amazon Mechanical Turkers, matched the photo file with the item's description and price-tag, and uploaded the result on the merchant's site..$^{30}$

But the development of the Internet as an interactive space and the growing role of social media, as opposed to the original one-directional mass media it was intended to be by the firms that originally invested in it - and which it still is to a very large extent -, resulting in the phrase "Web 2.0", has opened a new era which demands a refinement of the notion of spectacle, in its "spectacle 2.0" form. As Armano and Briziarelli put it: 
(...) the Spectacle 2.0 is characterized by an even more extended integration at the social and economic level by comprising both the moment of production and consumption and combining them together into an indissoluble whole. In fact, if the previous Spectacle relied on production and consumption as important but also separated moments and considerable more emphasis was given to the latter, the Spectacle 2.0 appears as the amalgamation of compound practices such as consumptive production and productive consumption. ${ }^{31}$ ourselves, we commodify ourselves, essentially visually, for the consumption of others, and we consume others as commodities. An inverted form of commodity fetishism is born, as Christian Fuchs observed, since relations between things take the shape of social relationships between people. ${ }^{32}$ Since all this activity is performed on "platforms," which disguise their capitalistic nature, our labor seems to produce this alienation of ours directly, to integrate us more deeply into the fabric of capitalism, to use the Marcusean notion. ${ }^{33}$ The more we see, the blinder we get.

\section{BIBLIOGRAPHY}

Apostolidès, Jean-Marie. Debord le Naufrageur. Paris: Flammarion, 2015.

Apter, Emily. Feminizing the Fetish: Psychoanalysis and Narrative Obsession in Turn-of-the Century France. Ithaca: Cornell UP, 1991.

Arnould, Eric J. "Global Consumer Culture”, in Sheth, Jagdish and Naresh Maholtra, eds.. Encyclopedia of International Marketing. New York : John Wiley and Sons, 2011: 183-192.

Baudrillard, Jean. Le Système des objets. Paris: Gallimard, 1968.

Baudrillard, Jean. America. London: Verso, 1988.

Baudrillard, Jean. La Société de consommation, ses mythes, ses structures. Paris: Denoël, 1970.

Bauman, Zygmunt, "Marxism and the Contemporary Theory of Culture", Co-Existence 5 (1968): 171-98.

Benjamin, Walter. "Expose of 1939" in Rolf Tiedemann ed., Howard Eiland and Kevin McLaughlin transl., The Arcades Project. Cambridge, Mass.: Harvard UP, 2002: 14-25.

Boorstin, Daniel. L'image ou ce qu'il advint du rêve américain. Paris: Julliard, 1963.

Boorstin, Daniel. The Image, or what happened to the American Dream. London: Weidenfeld and Nicolson, 1961.

Briziarelli, Marco and Emiliana Armano, eds. The Spectacle 2.0: Reading Debord in the Context of Digital Capitalism. London: University of Westminster Press, 2017. DOI: https://doi.org/10.16997/ book11.

Burrows, Edwin G. The Finest Building in America: The New York Crystal Palace 1853-1858. New York: Oxford University Press, 2018.

Debord, Guy. La Société du Spectacle. Paris: Champ Libre, (1967) 1992. 
Debord, Guy. Society of the Spectacle, translated by Ken Knapp. London: Rebel Press, 2005.

Featherstone, Mike. Consumer Culture and Postmodernism. Second edition, Los Angeles: Sage, 2007.

Ferreira Zacarias, Gabriel. “Expérience et représentation du sujet : une généalogie de l'art et de la pensée de Guy Debord”. PhD diss. University of Perpignan, 2014. https://www.theses.fr/ 2014PERP1205.pdf, downloaded March 11, 2018.

Fuchs, Christian. Culture and Economy in the Age of Social Media. London: Routledge, 2015.

Galbraith, John K. The Affluent Society. $40^{\text {th }}$ anniversary edition (printed in 1998), New York: Mariner Books, 1958.

Hapgood, Norman. The Advancing Hour. New York: Boni and Liveright, 1920.

Huws, Ursula. "Logged labour: a new paradigm of work organisation?". Work organisation, labour and globalisation 10-1: 7-26. DOI10.13169/workorgalaboglob.10.1.0007.

Kellner, Douglas. "Critical Theory, Commodities and the Consumer Society". Theory, Culture and Society 1 (3): 66-83 (1983).

Lewchuk, Wayne A. "Men and Monotony: Fraternalism as a Managerial Strategy at the Ford Motor Company”. The Journal of Economic History, 53 (4) (Dec. 1993): 824-856.

Marcuse, Herbert. One-Dimensional Man: Studies in the Ideology of Advanced Industrial Society. Boston, MA: Beacon Press, 1964.

Marx, Karl, and Friedrich Engels. Werke. Berlin, Karl Dietz Verlag, 1961. http://www.mlwerke.de/ me/me13/me13_015.htm, accessed February 12, 2018.

Marx, Karl. Capital: A Critique of Political Economy. London: Penguin Classics, 1990, Kindle edition 2010.

Mingione, Enzo. Sociologia della Vita Economica. Roma: Carocci, 1997.

Persky, Joseph. "Retrospectives: Consumer Sovereignty." Journal of Economic Perspectives (7) 1 (Winter 1993): 183-191.

Sanguinetti, Gianfranco. "Argent, sexe et pouvoir : à propos d'une fausse biographie de Guy Debord”, https://blogs.mediapart.fr/lechatetlasouris/blog/150116/argent-sexe-et-pouvoirpropos-d-une-fausse-biographie-de-guy-debord, accessed March 8, 2018.

Schiller, Daniel. Digital Capitalism - Networking the Global Market System. Cambridge, Mass.: MIT Press, 2000.

Smith, Adam (1776). An Inquiry into the Nature and Causes of the Wealth of Nations. Roy. H. Campbell, A.S. Skinner and W.B. Todd eds., 2 vols.. Oxford: Clarendon Press: 1976.

\section{ENDNOTES}

1. John Harris, "Guy Debord predicted our distracted society," The Guardian, March 30, 2012, https://www.theguardian.com/commentisfree/2012/mar/30/guy-debord-society-spectacle.

2. Marco Briziarelli and Emiliana Armano, eds., The Spectacle 2.0: Reading Debord in the Context of Digital Capitalism (London: University of Westminster Press, 2017). Kellner's preface is on pages 1-12. Kellner's effort at a synthesis of the two approaches on consumer culture started with his seminal "Critical Theory, Commodities and the Consumer Society" article of 1983 in Theory, Culture, \& Society (1(3), 66-83. 
3. Among the various terms used to name the period that incorporates the first decades of the $21^{\text {st }}$ century (neo-liberalism, post-Fordism, globalization, networked society, etc.), the phrase "digital capitalism" best captures the link between socioeconomic drivers and technological channels that affects consumer culture, and especially its visual dimensions. It is borrowed from the title of Daniel Schiller's book, Digital Capitalism - Networking the Global Market System (Cambridge, Mass.: MIT Press, 2000).

4. Karl Marx, Capital: A Critique of Political Economy (London: Penguin Classics, 1990), vol. 1, Kindle 2715-3034.

5. For a brilliant and erudite attempt at reconciling the various meanings of commodity fetishism, see Emily Apter's "Fetishism in Theory: Marx, Freud, Baudrillard", in her book Feminizing the Fetish: Psychoanalysis and Narrative Obsession in Turn-of-the Century France (Ithaca: Cornell UP, 1991), 1-14.

6. Marx, Capital, vol. 1, Kindle 2080-2082.

7. Both Marx and Debord would have benefited from the notion of wants, i.e., the way needs become conscious, are expressed and end up in a purchase. Wants are shaped by personal history, culture, and marketing stimuli like advertising. There are no "pseudo-needs." There are various ways of satisfying all sorts of human needs. Companies compete to change the order in which one consumer's needs are satisfied within a limited budget to obtain priority for the need satisfactions that they sell, shaping their target's wants so that they coincide with what they sell; but you cannot create needs. You can indeed persuade someone to buy a gun to satisfy a need for a feeling of security, crazy as that maybe, since owning a gun actually increases the chances of being killed; you can certainly persuade somebody to purchase a brand as a badge of distinction, although the customer getting his or her happiness jolt enjoys that "distinction" with millions; you can sell furniture as elements of a narrative about its proud owner, but it is really a master salesperson that sells a pool-cleaning robot to someone who does not own a pool.

8. Zygmunt Bauman, "Marxism and the Contemporary Theory of Culture," Co-Existence 5 (1968), 171-98.

9. Enzo Mingione, Sociologia della Vita Economica (Roma: Carocci, 1997), 158.

10. Eric J. Arnould, "Global Consumer Culture," in Encyclopedia of International Marketing, Jagdish Sheth and Naresh Maholtra, eds., (New York : John Wiley and Sons, 2011), 183-192, 183.

11. Adam Smith, An Inquiry into the Nature and Causes of the Wealth of Nations, Roy. H. Campbell, Andrew. S. Skinner and William. B. Todd, eds., 2 vols. (1776; Oxford: Clarendon Press, 1976) vol. 2, 660.

12. Joseph Persky, "Retrospectives: Consumer Sovereignty," Journal of Economic Perspectives (7) 1 (Winter 1993), 183-191.

13. Karl Marx, Capital: A Critique of Political Economy. Ernest Mendel, ed., vol. 1, Penguin Classics: 1990. Kindle edition (Kindle 18653-18654). Original German in Marx, Karl / Engels Friedrich Werke. Berlin, Karl Dietz Verlag: 1961, (13): 15. http://www.mlwerke.de/me/me13/ me13_015.htm, accessed August 12, 2018.

14. Jean Baudrillard, Le Système des objets (Paris: Gallimard, 1968).

15. Walter Benjamin, "Expose of 1939," in Rolf Tiedemann ed., Howard Eiland and Kevin McLaughlin transl., The Arcades Project (Cambridge, Mass.: Harvard UP, 2002), 14.

16. Edwin G. Burrows, The Finest Building in America: The New York Crystal Palace 1853-1858 (New York: Oxford University Press, 2018), 11.

17. Wayne A. Lewchuk, "Men and Monotony: Fraternalism as a Managerial Strategy at the Ford Motor Company," The Journal of Economic History, 53 (4) (Dec. 1993), 824-856.

18. Norman Hapgood, The Advancing Hour (New York: Boni and Liveright, 1920), 172. Jean Baudrillard, La Société de consommation, ses mythes, ses structures (Paris: Denoël, 1970). Daniel J. 
Boorstin, The Image, or what happened to the American Dream (New York: Atheneum, 1961), republished in 1964 as The Image: A Guide to Pseudo-events in America (New York and Boston: Harper and Row Books, 1964).

19. Gabriel Ferreira Zacarias, "Expérience et représentation du sujet : une généalogie de l'art et de la pensée de Guy Debord" (PhD diss. University of Perpignan, 2014), 580-581.

20. Guy Debord, La Société du spectacle (1967; Paris: Champ Libre, 1992), 12.

21. Debord, Société du spectacle, 6. Interestingly, the original title contemplated by Galbraith for his book was "Why People Are Poor." See Charlotte Curtis, "The Affluent Society, 1983," New York Times, November 22, 1983, http://www.nytimes.com/ 1983/11/22/arts/charlotte-curtis-affluent-society-1983-john-kenneth-galbraith-saffluent-society.html?pagewanted=print, accessed March 8, 2018.

22. See Debord's notes on Marcuse mentioned in Zacarias, “Expérience," 260.

23. John K. Galbraith, The Affluent Society (1958; New York: Mariner Books, 1998), 125.

24. I'm translating from the French original, using Ken Knapp's 2005 translation when best in my opinion (London: Rebel Press). The references are to the thesis numbers in all editions of $L a$ Société du Spectacle (SS).

25. Daniel Boorstin, L'image ou ce qu'il advint du rêve américain (Paris: Julliard, 1963).

26. Jean-Marie Apostolidès, Debord le Naufrageur (Paris: Flammarion, 2015), 233.

27. Apostolidès, Debord le Naufrageur, 236. Debord had a limited knowledge of English, which he affected to ignore completely.

28. Gianfranco Sanguinetti, 2015. “Argent, sexe et pouvoir: a propos d'une fausse biographie de Guy Debord", https://blogs.mediapart.fr/lechatetlasouris/blog/150116/ argent-sexe-et-pouvoir-propos-d-une-fausse-biographie-de-guy-debord, accessed March 8, 2018.

29. Ursula Huws, "Logged labour: a new paradigm of work organisation?," Work Organisation, Labour and Globalisation 10-1, 7-26. DOI10.13169/workorgalaboglob. 10.1.0007.

30. This is what Amazon calls "artificial artificial intelligence."

31. Briziarelli and Armano, Spectacle 2:0, 35.

32. Christian Fuchs, Culture and Economy in the Age of Social Media (London: Routledge, 2015), 230.

33. Herbert Marcuse, One-Dimensional man: Studies in the Ideology of Advanced Industrial Society (Boston, MA: Beacon Press, 1964).

\section{ABSTRACTS}

This paper argues that Debord's La Société du Spectacle was a syncretism of contemporary US criticism of the consumer society and the power of the image and of the Marxist tradition. First it elucidates the notion of commodity fetishism for Marx and Debord's détournement of it. It then establishes the connection between the history of consumer cultures, in terms of their visual dimension, with that of production systems. Then Debord's development of the notion of spectacle is analyzed as a typical critique of Fordism. Finally, the paper addresses the relevance of the concept of spectacle in the post-Fordist digital era.

\section{INDEX}

Keywords: Spectacle; Commodity Fetishism; Debord; Marx; Fordism. 


\section{AUTHOR}

\section{OLIVIER FRAYSSÉ}

Olivier Frayssé is Professor of American Studies at Sorbonne Université. A graduate of École Normale Supérieure and Institut d'Études Politiques de Paris, he currently codirects with Andrew Diamond the "Capitalism on the Ground" program of the Histoire et Dynamique des Espaces Anglophones (HDEA) research center. Frayssé's latest productions related to capitalism include "How the US Counterculture Redefined Work for the Age of the Internet", in Olivier Frayssé and Mathieu O'Neil (eds.), Digital Labour and Prosumer Capitalism: The US Matrix (Palgrave Macmillan, 2015), "Is the Concept of Rent Relevant to a Discussion of Surplus-Value in the Digital World?", in Eran Fisher and Christian Fuchs, (eds.), Reconsidering Value and Labour in the Digital Age (Palgrave Macmillan, 2016), "Guy Debord, a critique of modernism and Fordism: what lessons for today?" in Emiliana Armano and Marco Briziarelli, eds., The Spectacle 2.0: Reading Debord in the Context of Digital Capitalism, Westminster UP, 2017, and "The Relation Between Production, Labor Regimes and Leisure Forms: From slavery to digital capitalism", Angles, 2017. 